Article

\title{
New Thiophene and Flavonoid from Tagetes minuta Leaves Growing in Saudi Arabia
}

\author{
Nawal M. Al-Musayeib ${ }^{1, *}$, Gamal A. Mohamed ${ }^{2}$, Sabrin R. M. Ibrahim ${ }^{3}$ and Samir A. Ross ${ }^{4}$ \\ 1 Department of Pharmacognosy, Faculty of Pharmacy, King Saud University, Riyadh 11451, \\ Saudi Arabia \\ 2 Department of Pharmacognosy, Faculty of Pharmacy, Al-Azhar University, Assiut Branch, \\ Assiut 71524, Egypt; E-Mail: gamals2001@yahoo.com \\ 3 Department of Pharmacognosy, Faculty of Pharmacy, Assiut University, Assiut 71526, Egypt; \\ E-Mail: sabrinshaur@gmail.com \\ 4 National Center for Natural Products Research, Department of Pharmacognosy, School of Pharmacy, \\ The University of Mississippi, University, MS 38677, USA; E-Mail: sross@olemiss.edu \\ * Author to whom correspondence should be addressed; E-Mail: nalmusayeib@ksu.edu.sa; \\ Tel./Fax: +966-11-228-2584.
}

Received: 28 January 2014; in revised form: 25 February 2014 / Accepted: 25 February 2014 / Published: 4 March 2014

\begin{abstract}
Phytochemical investigation of the methanolic extract of Tagetes minuta L. (Asteraceae) leaves resulted in the isolation and identification of two new compounds: 5-methyl-2,2',5',2",5",2"',5"',2'"'-quinquethiophene (1) and quercetagetin-6-O-(6-Ocaffeoyl- $\beta$-D-glucopyranoside) (9), in addition to seven known compounds: quercetin-3,6dimethyl ether (2), quercetin-3-methyl ether (3), quercetin (4), axillarin-7- $O-\beta$-Dglucopyranoside (5), quercetagetin-3,7-dimethoxy-6- $O-\beta$-D-glucopyranoside (6), quercetagetin-7-methoxy-6- $O-\beta$-D-glucopyranoside (7), and quercetagetin-6- $O-\beta$-Dglucopyranoside (8). The compounds were identified by UV, IR, 1D, 2D NMR, and HRESIMS spectral data. They showed significant antioxidant activity, comparable with that of propyl gallate. Compounds $\mathbf{8}$ and $\mathbf{3}$ showed weak to moderate antileishmanial and antimalarial activities, with $\mathrm{IC}_{50}$ values of $31.0 \mu \mathrm{g} / \mathrm{mL}$ and $4.37 \mu \mathrm{g} / \mathrm{mL}$, respectively.
\end{abstract}

Keywords: Tagetes minuta; Asteraceae; thiophene; quercetagetin; antioxidant; antimicrobial; antileishmanial; antimalarial 


\section{Introduction}

The genus Tagetes (Asteraceae) is mainly native to the central and southern part of America. It consists of approximately 30 species [1]. Members of the genus Tagetes have a long history of human use as beverages, condiments, ornamentals, and medicinal decoctions. Tagetes minuta L. has been used as anthelmintic, diuretic, antispasmodic, and for treatment of stomach and intestinal diseases [2]. Tagetes oil is used as a flavor component in food products including cola and alcoholic beverages, frozen dairy desserts, candy, baked goods, gelatins, puddings, condiments, and relishes [3]. The oil has antibacterial [4], larvicidal [5], and insecticidal [6] activities. Previous phytochemical studies of $T$. minuta L. led to the isolation of terpenes [2,7], flavonoids [8], thiophenes, and aromatic compounds [9]. This article reports the isolation and characterization of two new compounds: 5-methyl-2,2',5',2",5",2'",5"',2"'-quinquethiophene (1) and quercetagetin-6- $O$-(6- $O$-caffeoyl- $\beta$-D-glucopyranoside) (9), together with seven known flavonoids (Figure 1).

Figure 1. Chemical structures of the isolated compounds 1-9.
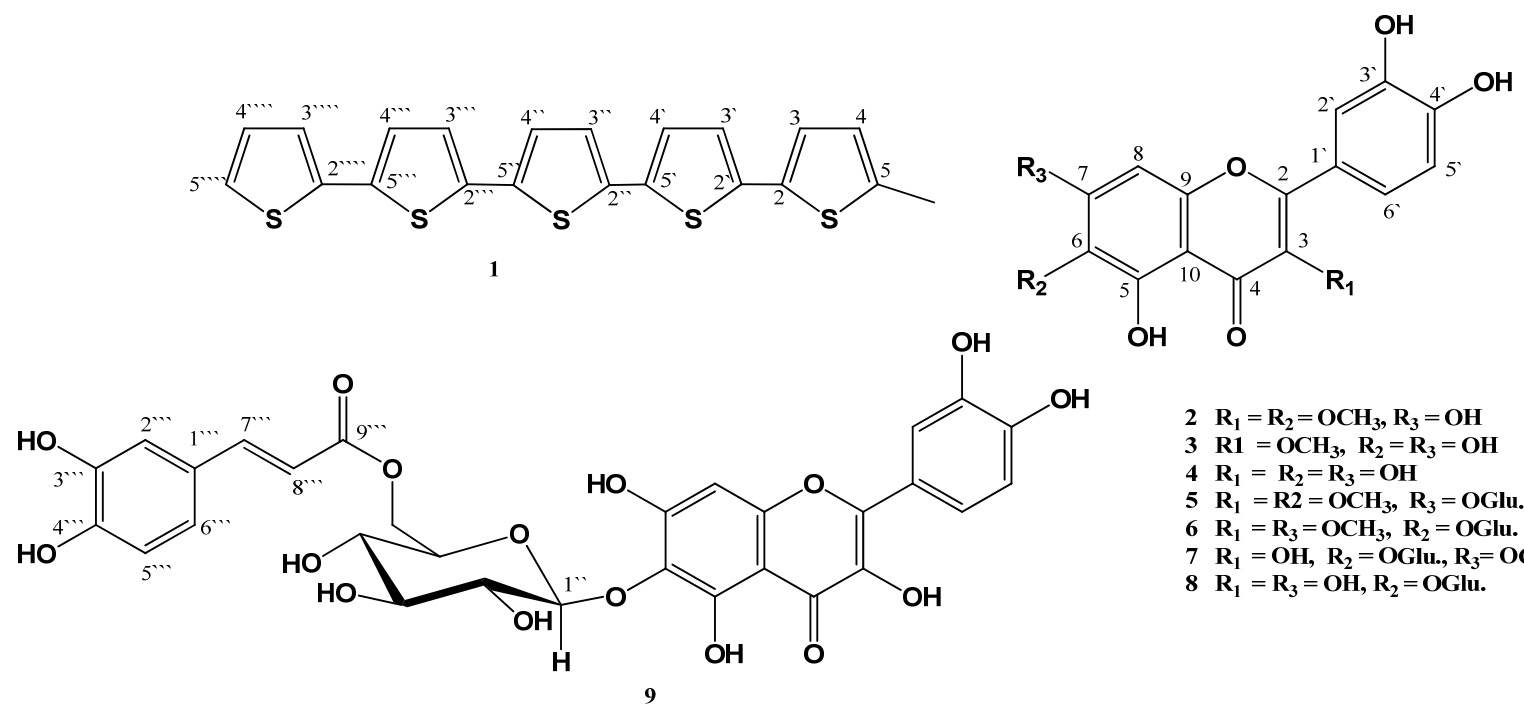

$2 \mathbf{R}_{1}=\mathbf{R}_{2}=\mathrm{OCH}_{3}, \mathbf{R}_{3}=\mathrm{OH}$

$3 \mathbf{R 1}=\mathrm{OCH}_{3}, \mathbf{R}_{2}=\mathbf{R}_{3}=\mathbf{O H}$

$4 \quad R_{1}=R_{2}=R_{3}=O H$

$5 \quad \mathbf{R}_{1}=\mathbf{R 2}=O \mathrm{OCH}_{3}, \mathbf{R}_{3}=$ OGlu.

$6 \quad \mathbf{R}_{1}=\mathbf{R}_{3}=\mathrm{OCH}_{3}, \mathbf{R}_{2}=$ OGlu.

$7 \quad \mathbf{R}_{1}=\mathrm{OH}, \mathbf{R}_{2}=$ OGlu., $\mathbf{R}_{3}=\mathrm{OCH}_{3}$

$8 \quad \mathbf{R}_{1}=\mathbf{R}_{3}=\mathbf{O H}, \mathbf{R}_{2}=$ OGlu.

\section{Results and Discussion}

Compound 1 was isolated as brown needles. HRESIMS gave an $[\mathrm{M}+\mathrm{H}]^{+}$at $\mathrm{m} / z 427.6611$ and $428.6613[\mathrm{M}+2 \mathrm{H}]^{+}$, which is consistent with the molecular formula $\mathrm{C}_{21} \mathrm{H}_{14} \mathrm{~S}_{5}$, implying fifteen degrees of unsaturation. The UV absorption maxima at 387 and $334 \mathrm{~nm}$ indicated the presence of quinquethiophene moiety [10,11]. The ${ }^{1} \mathrm{H}-\mathrm{NMR}$ spectrum showed eleven protons signals at $\delta_{\mathrm{H}} 6.64-7.21$ with coupling constants $5.5-3.5 \mathrm{~Hz}$ characteristic for 5-subsituted quinquethiophenes [11]. Additionally, the proton signal at $\delta_{\mathrm{H}} 2.42(3 \mathrm{H}, \mathrm{s})$ indicated the presence of a methyl group (Table 1). The ${ }^{13} \mathrm{C}$-NMR spectrum exhibited twenty one carbon resonances. The multiplicities of the carbons in $\mathbf{1}$ were confirmed with DEPT and HSQC experiments, which showed one methyl, eleven methines, and nine quaternary carbons. ${ }^{1} \mathrm{H}-{ }^{1} \mathrm{H}$ COSY provided five spin systems for five thiophene rings (Figure 2). The HMBC spectrum exhibited cross peaks from methyl protons at C-5 to C-4 and C-5. In HMBC spectrum, cross-peaks from H-3 to C-2', H-3' to C-2, H-4' to C-2", H-3" to C-5', H-4" to C-2"', H-3"' to C-5", H-4"' to C-2"', and H-3"'" to C-5"'confirmed the connectivity of thiophene rings [11]. 
Accordingly, 1 was 5-methyl-2, 2',5', 2",5",2"',5"',2"'--quinquethiophene. Compound 1 was isolated for the first time from natural origin.

Table 1. NMR spectral data for compound $1\left(\mathrm{CDCl}_{3}, 500\right.$ and $\left.125 \mathrm{MHz}\right)$.

\begin{tabular}{|c|c|c|c|}
\hline No. & $\delta_{\mathrm{H}}[$ mult., $J(\mathrm{~Hz})]$ & $\delta_{\mathrm{C}}$ (mult.) & НMBC \\
\hline 2 & - & $133.5(\mathrm{C})$ & - \\
\hline 3 & $6.93 \mathrm{~d}(3.5)$ & $125.9(\mathrm{CH})$ & $2,4,5$ \\
\hline 4 & 6.64 brs & $124.0(\mathrm{CH})$ & $2,3,5$ \\
\hline 5 & - & $137.3(\mathrm{C})$ & - \\
\hline $2^{\prime}$ & - & $134.2(\mathrm{C})$ & - \\
\hline $3^{\prime}$ & $6.97 \mathrm{~d}(3.5)$ & $121.2(\mathrm{CH})$ & 2 \\
\hline $4^{\prime}$ & $6.96 \mathrm{~d}(3.5)$ & $122.3(\mathrm{CH})$ & $2^{\prime}, 3^{\prime}, 2^{\prime \prime}$ \\
\hline $5^{\prime}$ & - & $128.9(\mathrm{C})$ & - \\
\hline $2^{\prime \prime}$ & - & $134.7(\mathrm{C})$ & - \\
\hline 3" & $6.98 \mathrm{~d}(3.5)$ & $121.5(\mathrm{CH})$ & 4"', $2 " '$ \\
\hline 4" & $7.02 \mathrm{~d}(3.5)$ & $122.3(\mathrm{CH})$ & $2 " '$ \\
\hline $5^{\prime \prime}$ & - & $126.1(\mathrm{C})$ & - \\
\hline $2^{\prime \prime \prime}$ & - & $135.1(\mathrm{C})$ & - \\
\hline 3"' & $6.99 \mathrm{~d}(3.5)$ & $125.8(\mathrm{CH})$ & 4"', 5"', 2"' \\
\hline 4"' & $7.12 \mathrm{~d}(3.5)$ & $121.6(\mathrm{CH})$ & 2"', $2 " ' ", 3 " ', 5 " '$ \\
\hline $5^{\prime \prime \prime}$ & - & $132.8(\mathrm{C})$ & - \\
\hline $2 " '$ & - & $135.3(\mathrm{C})$ & - \\
\hline $3^{\prime \prime \prime \prime}$ & 7.04 brs & $122.5(\mathrm{CH})$ & 4"'", 5"' \\
\hline $4^{\prime \prime \prime \prime}$ & 7.14 brd (3.5) & $121.7(\mathrm{CH})$ & 2"'", 3 "'" \\
\hline $5 " ' 1$ & 7.21 brd (5.5) & $123.0(\mathrm{CH})$ & 3"'", 4"'" \\
\hline $5-\mathrm{CH}_{3}$ & $2.42 \mathrm{~s}$ & $15.4\left(\mathrm{CH}_{3}\right)$ & 4,5 \\
\hline
\end{tabular}

Figure 2. ${ }^{1} \mathrm{H}-{ }^{1} \mathrm{H}$ COSY and $\mathrm{HMBC}$ correlations of $\mathbf{1}$ and 9.
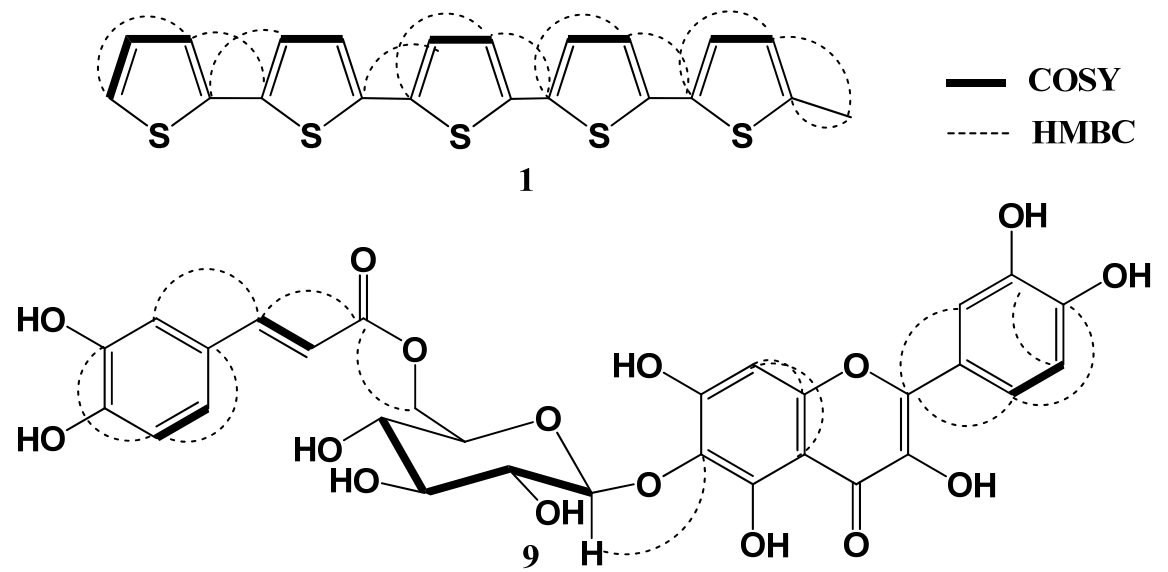

Compound 9 was isolated as a brown residue. It gave positive tests for flavonoids [12]. The HRESIMS spectrum showed a pseudo-molecular ion peak at $m / z$ 643.1223, consistent with a molecular formula $\mathrm{C}_{30} \mathrm{H}_{26} \mathrm{O}_{16}$. The UV spectrum of 9 showed absorption bands at 275 and $365 \mathrm{~nm}$ suggesting its flavonol nature [12]. IR spectrum showed absorption bands at 3,460 (OH), 2,976 (aromatic $\mathrm{C}-\mathrm{H}), 1,668($ ester $\mathrm{C}=\mathrm{O}), 1,608(\alpha, \beta$-unsaturated $\mathrm{C}=\mathrm{O})$, and 1,058 $(\mathrm{C}-\mathrm{O}) \mathrm{cm}^{-1}$. Analysis of 
the NMR spectra of 9 showed the presence of quercetagetin, trans-caffeoyl, and glucopyranosyl moieties and confirmed by significant fragment ion peaks at $\mathrm{m} / \mathrm{z} 480.0826\left[\mathrm{M}+\mathrm{H}\right.$-caffeoyl] ${ }^{+}$and $\mathrm{m} / \mathrm{z}$ $318.0299[\mathrm{M}+\mathrm{H}-(\text { caffeoyl+hexose })]^{+}$. The ${ }^{1} \mathrm{H}-\mathrm{NMR}$ spectrum revealed the presence of six singlets signals at $\delta_{\mathrm{H}} 6.59(\mathrm{H}-8), 8.50(3-\mathrm{OH}), 9.35\left(3^{\prime}-\mathrm{OH}\right), 9.35\left(4^{\prime}-\mathrm{OH}\right), 10.89(7-\mathrm{OH})$, and $12.24(5-\mathrm{OH})$. Also, it showed three coupled protons at $\left.\delta_{\mathrm{H}} 6.88(1 \mathrm{H}, \mathrm{d}, J=7.0 \mathrm{~Hz}, \mathrm{H}-5)^{\prime}\right), 7.57(1 \mathrm{H}, \mathrm{brd}, J=7.0 \mathrm{~Hz}$, H-6'), and $7.74(1 \mathrm{H}$, brs, H-2') for a tri-substituted B-ring (Table 2). Furthermore, an anomeric proton signal at $\delta_{\mathrm{H}} 5.02(1 \mathrm{H}, \mathrm{d}, J=6.5 \mathrm{~Hz}, \mathrm{H}-1 ")$ indicated $\beta$-configuration of the glycosidic linkage [13]. In addition, signals at $\delta_{\mathrm{H}} 6.96\left(1 \mathrm{H}, \mathrm{d}, J=1.5 \mathrm{~Hz}, \mathrm{H}-2{ }^{\prime \prime}\right), 6.93\left(1 \mathrm{H}, \mathrm{dd}, J=6.8,1.5 \mathrm{~Hz}, \mathrm{H}-6^{\prime \prime \prime}\right)$, and 6.77 $\left(1 \mathrm{H}, \mathrm{d}, J=6.8 \mathrm{~Hz}, \mathrm{H}-5{ }^{\prime \prime}\right)$ for a tri-substituted phenyl ring (ABX pattern) and two trans-coupled olefinic protons at $\delta_{\mathrm{H}} 7.43\left(1 \mathrm{H}, \mathrm{d}, J=16.0 \mathrm{~Hz}, \mathrm{H}-7^{\prime \prime \prime}\right)$ and $6.23\left(1 \mathrm{H}, \mathrm{d}, J=16.0 \mathrm{~Hz}, \mathrm{H}-8^{\prime \prime \prime}\right)$ indicating the presence of trans caffeyol moiety (Table 2) [14-16] in which confirmed by ${ }^{13} \mathrm{C}-\mathrm{NMR}$ signals at $\delta_{\mathrm{C}}$ 113.4 (C-8"'), 115.3 (C-5"'), 115.7 (C-2"'), 120.5 (C-6"'), 145.3 (C-4"'), 145.5 (C-7"'), 148.3 (C-3"'), and 166.5 (C-9'").

Table 2. NMR spectral data for compound 9 (DMSO- $d_{6}, 500$ and $125 \mathrm{MHz}$ ).

\begin{tabular}{|c|c|c|c|}
\hline No. & $\delta_{\mathrm{H}}[$ mult., $J(\mathrm{~Hz})]$ & $\delta_{\mathrm{C}}$ (mult.) & HMBC \\
\hline 2 & - & $148.1(\mathrm{C})$ & - \\
\hline 3 & - & $135.6(\mathrm{C})$ & - \\
\hline 4 & - & $176.1(\mathrm{C})$ & - \\
\hline 5 & - & $151.5(\mathrm{C})$ & - \\
\hline 6 & - & $129.6(\mathrm{C})$ & - \\
\hline 7 & - & $151.4(\mathrm{C})$ & \\
\hline 8 & $6.59 \mathrm{~s}$ & $93.5(\mathrm{CH})$ & $6,7,10$ \\
\hline 9 & - & $147.7(\mathrm{C})$ & - \\
\hline 10 & - & $105.1(\mathrm{C})$ & - \\
\hline $1^{\prime}$ & - & $122.0(\mathrm{C})$ & - \\
\hline $2^{\prime}$ & 7.74 brs & $115.5(\mathrm{CH})$ & $2,4^{\prime}, 6^{\prime}$ \\
\hline $3^{\prime}$ & - & $145.0(\mathrm{C})$ & - \\
\hline $4^{\prime}$ & - & $147.5(\mathrm{C})$ & - \\
\hline $5^{\prime}$ & $6.88 \mathrm{~d}(7.0)$ & $115.3(\mathrm{CH})$ & $3^{\prime}, 6^{\prime}$ \\
\hline $6^{\prime}$ & 7.57 brd (7.0) & $119.9(\mathrm{CH})$ & $2,1^{\prime}, 4^{\prime}$ \\
\hline $1 "$ & $5.02 \mathrm{~d}(6.5)$ & $100.9(\mathrm{CH})$ & 6 \\
\hline $2^{\prime \prime}$ & $3.77 \mathrm{dd}(7.0,9.0)$ & $73.1(\mathrm{CH})$ & - \\
\hline $3 "$ & $3.86 \mathrm{~m}$ & $75.7(\mathrm{CH})$ & - \\
\hline $4^{\prime \prime}$ & $3.23 \mathrm{dd}(9.0,9.5)$ & $69.6(\mathrm{CH})$ & - \\
\hline $5^{\prime \prime}$ & $4.35 \mathrm{~m}$ & $77.2(\mathrm{CH})$ & - \\
\hline 6" & $\begin{array}{l}4.41 \mathrm{dd}(2.8,12.0) \\
4.30 \mathrm{dd}(7.0,12.0)\end{array}$ & $64.6\left(\mathrm{CH}_{2}\right)$ & $9^{\prime \prime \prime}$ \\
\hline $1 " '$ & - & $125.2(\mathrm{C})$ & - \\
\hline $2^{\prime \prime \prime}$ & $6.96 \mathrm{~d}(1.5)$ & $115.7(\mathrm{CH})$ & 6"', 7"' \\
\hline $3^{\prime \prime \prime}$ & - & $148.3(\mathrm{C})$ & - \\
\hline $4^{\prime \prime \prime}$ & - & $145.3(\mathrm{C})$ & - \\
\hline $5 " '$ & $6.77 \mathrm{~d}(6.8)$ & $115.3(\mathrm{CH})$ & $3 " '$ \\
\hline $6^{\prime \prime \prime}$ & $6.93 \mathrm{dd}(1.5,6.8)$ & $120.5(\mathrm{CH})$ & 4"', 5"', 7"', 8"' \\
\hline
\end{tabular}


Table 2. Cont.

\begin{tabular}{cccc}
\hline No. & $\delta_{\mathbf{H}}[$ mult., $\boldsymbol{J}(\mathbf{H z})]$ & $\delta_{\mathrm{C}}$ (mult.) & HMBC \\
\hline $7 " '$ & $7.43 \mathrm{~d}(16.0)$ & $145.5(\mathrm{CH})$ & $9^{\prime \prime \prime}$ \\
$8 " '$ & $6.23 \mathrm{~d}(16.0)$ & $113.4(\mathrm{CH})$ & $1{ }^{\prime \prime \prime}, 9^{\prime \prime \prime}$ \\
$9 " '$ & - & $166.5(\mathrm{C})$ & - \\
$5-\mathrm{OH}$ & $12.24 \mathrm{~s}$ & - & - \\
$7-\mathrm{OH}$ & $10.89 \mathrm{~s}$ & - & - \\
$3 '-\mathrm{OH}$ & $9.35 \mathrm{~s}$ & - & - \\
$4 '-\mathrm{OH}$ & $9.35 \mathrm{~s}$ & - & - \\
$3-\mathrm{OH}$ & $8.50 \mathrm{~s}$ & - & - \\
\hline
\end{tabular}

The ${ }^{13} \mathrm{C}-\mathrm{NMR}$ spectrum displayed fifteen carbon signals were attributed to quercetagetin skeleton $[16,17]$ and six carbons for glucose. The multiplicity of each carbon was determined by HSQC experiment. The glucose moiety was located at C-6 based on the HMBC cross peak of $\mathrm{H}-1$ " at $\delta_{\mathrm{H}} 5.02(1 \mathrm{H}, \mathrm{d}, J=$ $6.5 \mathrm{~Hz})$ to $\mathrm{C}-6\left(\delta_{\mathrm{C}} 129.6\right)$ and further confirmed by its reaction with diagnostic shift reagents. In the HMBC spectrum, the methylene protons at $\delta_{\mathrm{H}} 4.41$ (H-6"B) and 4.30 (H-6"A) correlated with the caffeoyl carbonyl group at $\delta_{\mathrm{C}} 166.5$ suggesting the connectivity of caffeoyl moiety at C-6" and confirmed by the downfield shift of C-6" ( $\delta_{\mathrm{C}}$ 64.6). Acid hydrolysis of 9 afforded quercetagetin, caffeic acid, and $\beta$-D-glucose. They were identified by co-chromatography with authentic samples using (S5) [14]. Accordingly, 9 was identified as quercetagetin-6- $O$-(6- $O$-caffeoyl- $\beta$-D-glucopyranoside).

The other compounds were identified as quercetin-3,6-dimethyl ether (2) [18], quercetin-3-methyl ether (3) [18], quercetin (4) [18], axillarin-7- $O-\beta$-D-glucopyranoside (5) [19], quercetagetin-3,7dimethoxy-6- $O-\beta$-D-glucopyranoside (6) [20], quercetagetin-7-methoxy-6- $O$ - $\beta$-D-glucopyranoside (7) [20], and quercetagetin-6-O- $\beta$-D-glucopyranoside (8) [20] by comparison of their physical and spectral data with those in the literature. The antioxidant activity of the isolated compounds $\mathbf{2 - 9}$ was determined by using a DPPH free radical scavenging system. The antioxidant percentage activity ranged from 91.6 to $68.3 \%$ (Table 3). The antioxidant effect of these compounds was related to the number of free phenolic hydroxyl groups in the 3,4-dihydroxy form in their structures, which explains the close similarity of their antioxidant activity. Absence or blocking of the hydroxyl groups by a methyl or glucose moiety leads to a decrease of the antioxidant activity [21].

Table 3. Antioxidant activity of the isolated compounds.

\begin{tabular}{cc}
\hline Comp. & \% Activity \\
\hline 2 & 81.1 \\
3 & 82.4 \\
4 & 91.6 \\
5 & 68.3 \\
6 & 69.1 \\
7 & 71.3 \\
8 & 83.0 \\
9 & 89.1 \\
\hline
\end{tabular}

Compounds 1-9 were evaluated for their antimicrobial, antimalarial and antileishmanial activities. None of the isolated compounds 1-9 showed any antimicrobial activity. Compound 8 showed weak 
antileishmanial activity with an $\mathrm{IC}_{50} 31.0 \mu \mathrm{g} / \mathrm{mL}$. Compound $\mathbf{3}$ showed moderate antimalarial activity against chloroquine sensitive (D6) clones of $P$. falciparum with an $\mathrm{IC}_{50}$ of $4.37 \mu \mathrm{g} / \mathrm{mL}$.

\section{Experimental}

\subsection{General Procedures}

Melting points were measured on an Electrothermal 9100 Digital Melting Point apparatus (Electrothermal Engineering Ltd, Essex, England). Optical rotation was measured with a Perkin-Elmer 241 automatic polarimeter (Perkin-Elmer Inc, Massachusetts, MA, USA). HRESIMS was recorded on a LTQ Orbitrap (ThermoFinnigan, Bremen, Germany) mass spectrometer. Low resolution mass spectra were determined using a Finnigan MAT TSQ-7000 mass spectrometer. UV spectra were recorded on a Shimadzu 1601 UV/VIS spectrophotometer (Kyoto, Japan). The IR spectra were measured on a Shimadzu Infrared-400 spectrophotometer. 1D and 2D NMR spectra were recorded on a Bruker Avance DRX 500 instrument (Bruker BioSpin, Massachusetts, MA, USA). Column chromatography separations were performed on silica gel $60(0.04-0.063 \mathrm{~mm}), \mathrm{RP}_{18}(0.04-0.063 \mathrm{~mm}$ Merck, Darmstadt, Germany), and Sephadex LH-20 (0.25-0.1 mm, Merck, Darmstadt, Germany). TLC was performed on pre-coated plates with silica gel $60 \mathrm{~F}_{254}(0.2 \mathrm{~mm}$, Merck). The solvent systems used for TLC analyses were $n$-hexane/EtOAc (97:3, S1), $\mathrm{CHCl}_{3} / \mathrm{MeOH}(95: 5, \mathrm{~S} 2), \mathrm{CHCl}_{3} / \mathrm{MeOH}$ (90:10, S3), $\mathrm{CHCl}_{3} / \mathrm{MeOH}(85: 15, \mathrm{~S} 4)$, and $n-\mathrm{BuOH} / \mathrm{HOAc} / \mathrm{H}_{2} \mathrm{O}(4: 1: 5, \mathrm{~S} 5)$.

\subsection{Plant Material}

The leaves of Tagetes minuta L. (Asteraceae) were collected in June 2012 from Al-Baha, Saudi Arabia. The plant was identified by Dr. A. A. Fayed, Prof. of Plant Taxonomy, Faculty of Science, Assiut University, Egypt. A voucher specimen (TM-1-2012) was deposited at the herbarium of the research center for medicinal, aromatic and poisonous plants, King Saud University.

\subsection{Extraction and Isolation}

The air-dried powdered leaves $(1.1 \mathrm{~kg})$ were extracted with $\mathrm{MeOH}(4 \times 5 \mathrm{~L}, 24 \mathrm{~h}$ each) at room temperature. The combined extracts were concentrated under reduced pressure to afford a dark green residue $(30.8 \mathrm{~g})$ which was suspended in distilled water $(250 \mathrm{~mL})$ then partitioned successively between $n$-hexane $(3 \times 500 \mathrm{~mL})$, EtOAc $(3 \times 500 \mathrm{~mL})$, and $n$-BuOH $(3 \times 500 \mathrm{~mL})$. Each fraction was concentrated to give $n$-hexane $(4.2 \mathrm{~g})$, EtOAc $(3.1 \mathrm{~g}), n$-BuOH $(2.6 \mathrm{~g})$, and aqueous (17.8 g) fractions. The $n$-hexane fraction (4.2 g) was subjected to vacuum liquid chromatography (VLC) using a $n$-hexane-EtOAc gradient to afford four subfractions: H-1 to H-4. Subfraction H-1 (0.52 g) was chromatographed over a silica gel column $(100 \mathrm{~g} \times 50 \times 2 \mathrm{~cm})$ using $n$-hexane/EtOAc (99:1 to 90:10) to give 1 (17 mg, brown needles). The EtOAc fraction $(3.1 \mathrm{~g})$ was subjected to VLC using a $\mathrm{CHCl}_{3}$ $\mathrm{MeOH}$ gradient, to afford four subfractions: E-1 to E-4. Subfraction E-1 (0.69 g) was chromatographed over a silica gel column $(100 \mathrm{~g} \times 50 \times 2 \mathrm{~cm})$ using $\mathrm{CHCl}_{3}-\mathrm{MeOH}$ gradients to give $2(12 \mathrm{mg}$, yellow needles) and 3 (17 mg, yellow needles). Subfraction E-2 (0.90 g) was similarly like subfraction E-1 to give 4 (9 mg, yellow needles). Silica gel column chromatography of subfraction E-3 $(0.51 \mathrm{~g})$ $(150 \mathrm{~g} \times 50 \times 3 \mathrm{~cm})$ using $\mathrm{CHCl}_{3}-\mathrm{MeOH}$ gradients yielded $5(11 \mathrm{mg}$, yellow residue $)$ and $6(7 \mathrm{mg}$, 
yellow residue). Subfraction E-4 (0.81 g) was chromatographed over a Sephadex LH-20 column $(100 \mathrm{~g} \times 50 \times 3 \mathrm{~cm})$ using $\mathrm{MeOH}$ as an eluent to give two subfractions: E-4A $(295 \mathrm{mg})$ and E-4B (430 mg). Subfraction E-4B was subjected to $\mathrm{RP}_{18}$ column chromatography $(100 \mathrm{~g} \times 50 \times 2 \mathrm{~cm})$ using a $\mathrm{MeOH}-\mathrm{H}_{2} \mathrm{O}$ gradient to afford 7 (16 mg, yellow residue). The $n-\mathrm{BuOH}$ fraction (2.6 g) was subjected to Sephadex LH-20 column chromatography $(100 \mathrm{~g} \times 50 \times 3 \mathrm{~cm})$ using $\mathrm{MeOH}$ as an eluent to give three subfractions: B-1 (611 mg), B-2 (355 mg), and B-3 (760 mg). Separately, subfractions B-2 and B-3, each one was chromatographed over a $\mathrm{RP}_{18}$ column $(40 \mathrm{~g} \times 25 \times 1 \mathrm{~cm})$ using a $\mathrm{MeOH}-\mathrm{H}_{2} \mathrm{O}$ gradient to give 8 (13 mg, yellow residue) and 9 (11 mg, brown residue). The other subfractions were retained for further investigation.

\subsection{Spectral Data}

5-Methyl-2,2',5',2',5",2'",,5"',2'"'-quinquethiophene (1). Brown needles (17 mg), m.p. 215-216 ${ }^{\circ} \mathrm{C}$. $\mathrm{R}_{f} 0.86$, silica gel $60 \mathrm{~F}_{254}(\mathrm{~S} 1)$. UV (MeOH): $\lambda_{\max } 334,387 \mathrm{~nm}$. IR $(\mathrm{KBr}): v_{\max } 2870,1600 \mathrm{~cm}^{-1}$. NMR data: see Table 1. HRESIMS: $m / z 427.6611$ (calcd for $\mathrm{C}_{21} \mathrm{H}_{15} \mathrm{~S}_{5},[\mathrm{M}+\mathrm{H}]^{+}, 427.6609$ ); 428.6613 (calcd for $\left.\mathrm{C}_{21} \mathrm{H}_{16} \mathrm{~S}_{5},[\mathrm{M}+2 \mathrm{H}]^{+}, 428.6609\right)$.

Quercetagetin-6-O-(6-O-caffeoyl- $\beta$-D-glucopyranoside) (9). Brown residue (11 mg), $\mathrm{R}_{f} 0.76$, silica gel $60 \mathrm{~F}_{254}(\mathrm{~S} 4) .[\alpha]_{\mathrm{D}}-176(0.5, \mathrm{MeOH})$. UV (MeOH): $\lambda_{\max } 275,365 \mathrm{~nm} ;+\mathrm{NaOMe}: 282,405 \mathrm{~nm} ;+\mathrm{AlCl}_{3}$ : 295, $410 \mathrm{~nm}$; +AlCl$/ \mathrm{HCl}: 293388 \mathrm{~nm}$; +NaOAc: 296, $385 \mathrm{~nm}$; +NaOAc/H $\mathrm{BO}_{3}$ : 280, $385 \mathrm{~nm}$. IR (KBr): $v_{\max } 3460,2976,1668,1608,1565,1058 \mathrm{~cm}^{-1}$. NMR data: see Table 2. HRESIMS: $\mathrm{m} / z$ 643.1223 (calcd for $\mathrm{C}_{30} \mathrm{H}_{27} \mathrm{O}_{16},[\mathrm{M}+\mathrm{H}]^{+}, 643.1221$ ).

\subsection{Acid Hydrolysis of 9}

Compound 9 (3 mg) was refluxed in $10 \mathrm{~mL}$ of $1 \mathrm{~N} \mathrm{HCl}$ for $4 \mathrm{~h}$. The aglycone was extracted with $\mathrm{CHCl}_{3}$. The sugar in the aqueous layer was identified by co-paper chromatography (PC) with authentic materials using solvent system (S5) and aniline phthalate spray as detection reagent [14].

\subsection{Antimicrobial Assay}

All the isolated compounds 2-9 were tested for antimicrobial activity against Candida albicans ATCC 90028, Candida glabrata ATCC90030, Candida krusei ATCC 6258, Asperigillus fumigates ATCC 90906, methicillin-resistant Staphylococcus aureus ATCC 33591, Cryptococcus neoformans ATCC 90113, Staphylococcus aureus ATCC 2921, Escherichia coli ATCC 35218, Pseudomonus aeruginosa ATCC 27853, and Mycobacterium intracellulare ATCC 23068 as described previously [22-24]. Ciprofloxacin and amphotericin B were used as positive standards.

\subsection{Antimalarial Assay}

The isolated compounds were tested on chloroquine sensitive (D6, Sierraleon) and resistant (W2, Indo-china) strains of Plasmodium falciparum using previously reported method [22,25]. Artemisinin and chloroquine were included in each assay as anti-malarial drug controls. 


\subsection{Antileishmanial Assay}

The anti-leishmanial activity of the isolated metabolites was tested in vitro against a culture of L. donovani promastigotes as previously outlined [26]. Pentamidine and amphoterecin B were used as positive standards.

\subsection{Antioxidant Activity}

The antioxidant activity of the isolated compounds 2-9 $(20 \mu \mathrm{M})$ in DPPH solution (4 mg was dissolved in HPLC MeOH $50 \mathrm{~mL}$ to obtain a concentration $80 \mu \mathrm{g} / \mathrm{mL}$ ) was determined as previously outlined [27-29].

\section{Conclusions}

In conclusion, in this study nine compounds were isolated and elucidated from T. minuta L. two of them (compounds $\mathbf{1}$ and 9) are new. The antioxidant, antimicrobial, antimalarial, and antileishmanial activities of the isolated compounds were evaluated. They showed antioxidant activity ranging from $91.6 \%$ to $68.3 \%$. Compound 8 showed weak antileishmanial activity with an $\mathrm{IC}_{50} 31.0 \mu \mathrm{g} / \mathrm{mL}$, while compound 3 showed moderate antimalarial activity against chloroquine sensitive (D6) clones of $P$. falciparum with an $\mathrm{IC}_{50} 4.37 \mu \mathrm{g} / \mathrm{mL}$.

\section{Acknowledgments}

The authors are grateful to the research center for female scientific and medical colleges, deanship of scientific research in King Saud University for the financial support and to Volker Brecht (Nuclear Magnetics Resonance, Institute fuer Pharmazeutische Wissenschaften, Albert-Ludwigs-Universität Freiburg, Germany) for HRMS measurements. Also, the authors are thankful to Melissa Jacobs, Shabana Khan, and Babu Tekwani for antimicrobial, anti-malarial, and anti-leishmanial testing.

\section{Conflicts of Interest}

The authors declare no conflict of interest

\section{References}

1. Loockerman, D.J.; Turner, B.L.; Jansen, R.K. Phylogenetic relationships within the Tageteae (Asteraceae) based on nuclear ribosomal ITS and chloroplast ndhF gene sequences. Syst. Bot. 2003, 28, 191-207.

2. EL-Deeb, K.S.; Abbas, F.A.; El Fishawy, A.; Mossa, J.S. Chemical composition of the essential oil of Tagetes minuta growing in Saudi Arabia. Saudi Pharm. J. 2004, 12, 51-53.

3. Leung, A.Y. Encyclopedia of Common Natural Ingredients. Essential Oils of Tagetes minuta from Brasil; Wiley: New York, NY, USA, 1980.

4. Senatore, F.; Napolitano, F.; Mohamed, M.A.H.; Harris, P.J.C.; Mn keni, P.N.S.; Henderson, J. Antibacterial activity of Tagetes minuta L. (Asteraceae) essential oil with different chemical composition. Flavour Fragance J.. 2004, 19, 574-578. 
5. Hadjiakhoondi, A.; Vatandoost, H.; Khanavi, M.; Abaee, M.R.; Karami, M. Biochemical investigation of different extracts and larvicidal activity of Tagetes minuta L. on Anopheles stephensi Larvae. Iran. J. Pharm. Sci. 2005, 1, 81-84.

6. Shahzadi, I.; Hassan, A.; Khan, U.W.; Shah, M.M. Evaluating biological activities of the seed extracts from Tagetes minuta L. found in Northern Pakistan. J. Med. Plants Res. 2010, 4, 2108-2112.

7. López, M.L.; Bonzani, N.E.; Zygadlo, J.A. Allelopathic potential of Tagetes minuta terpenes by a chemical, anatomical, and phytotoxic approach. Biochem. Syst. Ecol. 2009, 36, 882-890.

8. Tereschuk, M.L.; Riera, M.V.Q.; Castro, G.R.; Abdala, L.R. Antimicrobial activity of flavonoids from leaves of Tagetes minuta. J. Ethnopharmacol. 1997, 56, 227-232.

9. Xu, L.-W.; Chen, J.; Qi, H.-Y.; Shi, Y.-P. Phytochemicals and their biological activities of plants in Tagetes L. Chin. Herb. Med. 2012, 4, 103-117.

10. Bano, H.; Ahmed, S.W.; Azhar, I.; Ali, M.S.; Alam, N. Chemical constituents of Tagetes Patula L. Pak. J. Pharm. Sci. 2002, 15, 1-12.

11. Melucci, M.; Barbarella, G.; Zambianchi, M.; di Pietro, P.; Bongini, A. Solution-phase microwave-assisted synthesis of un-substituted and modified $\alpha$-quinque- and sexithiophenes. J. Org. Chem. 2004, 69, 4821-4828.

12. Harborne, J.B.; Mabry, H. The Flavonoids; Chapman\& Hall: New York, NY, USA, 1975.

13. Agrawal, P.K. NMR spectroscopy in the structural elucidation of oligosaccharides and glycosides. Phytochemistry 1992, 31, 3307-3330.

14. Sayed, H.M.; Mohamed, M.H.; Farag, S.F.; Mohamed, G.A.; Proksch, P. A new steroid glycoside and furochromones from Cyperus rotundus L. Nat. Prod. Res. 2007, 21, 343-350.

15. El-Shanawany, M.A.; Sayed, H.M.; Ibrahim, S.R.M.; Fayed, M.A.A.; Radwan, M.M.; Ross, S.A. A new isoflavone from Blepharis ciliaris of an Egyptian origin. Med. Chem. Res. 2012, 19, 2346-2350.

16. Parejo, I.; Bastida, J.; Viladomat, F.; Codina, C. Acylated quercetagetin glycosides with antioxidant activity from Tagetes maxima. Phytochemistry 2005, 66, 2356-2362.

17. Michels, G.; Mohamed, G.A.; Weber, N.; Chovolou, Y.; Kampkötter, A.; Wätjen, W.; Proksch, P. Effects of methylated derivatives of luteolin isolated from Cyperus alopecuroides in Rat H4IIE hepatoma cells. Basic Clin. Pharmacol. Toxicol. 2006, 98, 168-172.

18. Mohamed, G.A.; Ibrahim, S.R.M.; Sayed, H.M. Phenolic constituents of Cucurbita pepo L. cv 'Eskandrani' (Summer Squash) flowers. Bull. Pharm. Sci. 2009, 32, 311-319.

19. Schmeda-Hirschmanna, G.; Tapia, A.; Theoduloz, C.; Rodriguez, J.; López, S.; Feresin, G.E. Free radical scavengers and antioxidants from Tagetes mendocina. Z. Naturforsch. 2004, 59c, 345-353.

20. Harborne, J.B. The Flavonoids Advances in Research since 1980; Chapman \& Hall: New York, NY, USA, 1988.

21. Dugas, A.J., Jr.; Castañeda-Acosta, J.; Bonin, G.C.; Price, K.L.; Fischer, N.H.; Winston, G.W. Evaluation of the total peroxyl radical-scavenging capacity of flavonoids: Structure-activity relationships. J. Nat. Prod. 2000, 63, 327-331.

22. Bharate, S.B.; Khan, S.I.; Yunus, N.A.M.; Chauthe, S.K.; Jacob, M.R.; Tekwani, B.L.; Khan, I.A.; Singh, I.P. Anti-protozoal and antimicrobial activities of $O$-alkylated and formylated acylphloroglucinols. Bioorg. Med. Chem. 2007, 15, 87-96. 
23. Radwan, M.M.; Rodriguez-Guzman, R.; Manly, S.P.; Jacob, M.; Ross, S.A. Sepicanin A-A new geranyl flavanone from Artocarpus sepicanus with activity against methicillin-resistant Staphylococcus aureus (MRSA). Phytochem. Lett. 2009, 2, 141-143.

24. Ibrahim, S.R.M.; Mohamed, G.A.; Al-Musayeib, N.M. New constituents from the rhizomes of Egyptian Iris germanica L. Molecules 2012, 17, 2587-2598.

25. El-Shanawany, M.A.; Ross, S.A.; Ibrahim, S.R.M.; Mohamed, G.A.; Nafady, A.M. A new xanthone from the roots of Centaurium spicatum L. Phytochem. Lett. 2011, 4, 126-128.

26. Abdel-Mageed, W.M.; Backheet, E.Y.; Khalifa, A.A.; Ibraheim, Z.Z.; Ross, S.A. Antiparasitic antioxidant phenylpropanoids and iridoid glycosides from Tecoma mollis. Fitoterapia 2012, 83, 500-507.

27. Al-Musayeib, N.M.; Mohamed, G.A.; Ibrahim, S.R.M.; Ross, S.A. Lupeol-3-O-decanoate, a new triterpene ester from Cadaba farinosa Forssk. growing in Saudi Arabia. Med. Chem. Res. 2013, 22, 5297-5302.

28. Mohamed, G.A. Alliuocide A. A new antioxidant flavonoid from Allium cepa $L$. Phytopharmacology 2013, 4, 220-227.

29. Mohamed, G.A.; Ibrahim, S.R.M.; Al-Musayeib, N.M.; Ross, S.A. New anti-inflammatory flavonoids from Cadaba glandulosa Forssk. Arch. Pharm. Res. 2014, doi:10.1007/s12272-0130305-1.

Sample Availability: Samples of the isolated compounds are available from the authors.

(C) 2014 by the authors; licensee MDPI, Basel, Switzerland. This article is an open access article distributed under the terms and conditions of the Creative Commons Attribution license (http://creativecommons.org/licenses/by/3.0/). 